\title{
APLIKASI PENGELOLAAN DAN PERJUALAN BARANG-BARANG GSM (GENERAL MARCHANDISE) PADA PT.INTICAKRAWALA CITRA
}

\author{
Dani Musthofa ${ }^{1}$,Suranto Saputra², Nia Damayanti ${ }^{3}$ \\ 1,2,3 Teknik Informatika, FTIK, Universitas Indraprasta PGRI \\ Jalan Raya Tengah No 80, Kelurahan Gedong,Pasar Rebo,Jakarta Timur \\ 1.1musthofa77@gmail.com, ${ }^{2}$ surantounindra@yahoo.co.id, ${ }^{3}$ nia88damayanti@gmail.com
}

\begin{abstract}
ABSTRAK
Rancangan Aplikasi Pengelolaan dan Penjualan barang-barang GSM (General Marchandise) Pada PT.Inticakrawala Citra Dalam era globalisasi sekarang ini, teknologi informasi melaju dengan cepatnya. Adapun komputer yang merupakan peralatan yang diciptakan untuk mempermudah pekerjaan manusia, saat mencapai kemajuan baik di dalam pembuatan hardware maupun software. PT. Inti Cakrawala Citra (Toko Indogrosir) membutuhkan sekali adanya suatu sistem yang dapat menunjang dan mempermudah pekerjaan karyawan untuk mendapatkan hasil yang baik dan berdampak kepada pelayanan terhadap customer. Metode penelitian yang digunakan oleh penulis adalah metode kualitatif yaitu suatu penelitian yang berfokus membangun teori dari data atau fakta. Mengembangkan sintesa interaksi dan teori-teori yang dibangun dari fakta-fakta mendasar (grounded) mengembangkan pengertian dan sebagainya, berarti setiap langkah mengutamakan proses, apa adanya dan tanpa dibatasi norma-norma, rumus, dan seterusnya. Melalui pendekatan secara kualitatif penulis mengembangkan data melalui pendekatan yang didalam proses penelitian, turun kelapangan, menganalisis data dan kesimpulan data sampai dengan penulisannya mempergunakan aspekaspek kecenderungan, wawancara (interview), analisis isi dan story.Hasil dari penelitian ini adalah suatu sistem yang dapat digunakan untuk memudahkan pekerjaan Staff (karyawan) dalam mengelola data penjualan barang dan pegelolaan data barang sehingga dapat terselesaikan secara lebih cepat, tepat, akurat Serta efisien.
\end{abstract}

Kata Kunci: Aplikasi, Pengelolaan, Penjualan, General Marchandise.

\begin{abstract}
Application Design for Management and Sales of GSM (General Marchandise) goods at PT.Inticakrawala Citra In today's era of globalization, information technology is advancing rapidly. As for computers, which are equipment created to facilitate human work, when achieving progress both in the manufacture of hardware and software. PT. Inti Cakrawala Citra (Toko Indogrosir) needs a system that can support and facilitate the work of employees to get good results and have an impact on customer service. The research method used by the author is a qualitative method, which is a study that focuses on building theory from data or facts. Developing a synthesis of interactions and theories built from grounded facts, developing understanding and so on, means that each step prioritizes the process, as it is and without being limited by norms, formulas, and so on. Through a qualitative approach the writer develops data through an approach that in the research process, goes down the field, analyzes data and data conclusions until the writing uses aspects of tendencies, interviews) content analysis and stories. The results of this study are a system that can used to facilitate the work of staff (employees) in managing data on sales of goods and managing goods data so that they can be completed more quickly, precisely, accurately and efficiently.
\end{abstract}

Key Word: Application, Management, Sales, General Merchandi

\section{PENDAHULUAN}

Pada saat ini sistem aplikasi sangat berpengaruh disegala bidang kehidupan baik dibidang politik, pendidikan, maupun ekonomi, khususnya perdagangan (Khasbi, Nugraha, \& Muzid, 2016).Tetapi dalam kenyataan masih banyak ditemukan perusahaan yang masih menerapkan metode manual dan sistem manajemen dan administrasinya (Fadel Nuariko, 2017). Sehingga kesiapan untuk melayani kebutuhan para karyawan belum maksimal dan menyulitkan dalam pengontrolan data dan pembuatan laporan kepada pimpinan. Untuk menghasilkan mutu informasi yang baik, serta secara akurat dalam memperbaiki kesalahan-kesalahan yang sedang terjadi dalam pekerjaan dengan sistem yang manual, maka perusahaan membutuhkan suatu sistem komputer yang dapat membantu kinerja serta mengefesiensikan berbagai sumber daya seperti waktu dan semua sumber daya (Tri Istikomah, W. P, 2013). Proses manajemen dan 
pencatatan data tidak bisa dipisahkan dengan suatu perkembangan teknologi informasi, dikarenakan setiap keputusan manajemen selalu membutuhkan dukungan dari teknologi informasi begitu pula dengan manajemen data (Eri mardiani, N. R,2017).

Sistem adalah setiap sesuatu terdiri dari obyekobyek, atau unsur-unsur, atau komponenkomponen yang bertata kaitan dan bertata hubungan satu sama lain, sedemikian rupa sehingga unsur-unsur tersebut merupakan satu kesatuan pemrosesan atau pengolahan yang tertentu Moekijat (2011:152). Secara sederhana (Sutabri, T, 2012 ) menerangkan bahwa sistem dapat diartikan sebagai suatu kumpulan himpunan dari unsur, komponen atau variabelvariabel yang teroganisasi, saling berinteraksi, saling tergantung satu sama lain dan terpadu. Pengembangan sistem (system defelopment) dapat berarti dapat menyusun suatu sistem yang baru untuk menggantikan sistem yang lama secara keseluruhan atau memperbaiki sistem yang telah ada. Diharapkan dengan adanya suatu sistem informasi dapat menangani permasalahan yang ada di perusahaan tersebut. Pembangunan sistem adalah sekumpulan aktivitas yang menggambarkan secara rinci bagaimana sistem akan berjalan. Hal itu bertujuan untuk menghasilkan produk perangkat lunak yang sesuai dengan kebutuhan user (Sutarman, 2012). Diharapkan dengan adanya suatu sistem informasi dapat menangani permasalahan yang ada di perusahaan tersebut.Sistem dapat diartikan sebagai suatu kumpulan atau himpunan dari unsur, komponen, atau variabel yang terorganisir, saling berinteraksi, saling tergantung satu sama lain, dan terpadu. Dari pendapat yang dikemukakan di atas dapat disimpulkan bahwa sistem adalah suatu kupulan atau kelompok dari elemen atau komponen yang saling berhubungan atau saling berinteraksi dan saling bergantung satu sama lain untuk mencapai tujuan tertentu.” ( Edih Sutanta, 2011).

Tujuan penelitian adalah merancang suatu sistem informasi pengelolaan dan penjualan barangbarang GMS (General Marchandise ) yang diharapkan bisa mempermudah perusahaan dalam mengolah data dan melaporkan informasi yang berkaitan dengan pembelian, penjualan dan persediaan barang .

\section{METODE PENELITIAN}

Metode penelitian yang digunakan oleh penulis adalah metode kualitatif yaitu suatu penelitian yang berfokus membangun teori dari data atau fakta. Mengembangkan sintesa interaksi dan teori-teori yang dibangun dari fakta-fakta mendasar (grounded) mengembangkan pengertian dan sebagainya, berarti setiap langkah mengutamakan proses, apa adanya dan tanpa dibatasi norma-norma, rumus, dan seterusnya (Erwin, 2014). Melalui pendekatan secara kualitatif penulis mengembangkan data melalui pendekatan yang didalam proses penelitian, turun kelapangan, menganalisis data dan kesimpulan data sampai dengan penulisannya mempergunakan aspek-aspek kecenderungan, wawancara (interview), analisis isi dan story (Mulato, 2015). Salah satu factor penting dalam pembangunan/pengembangan sistem informasi ialah memahami sistem yang ada dan permasalahannya. Selain harus mengetahui bagian-bagian mana saja yang akan dipelajari. Beberapa teknik yang penulis gunakan antara lain untuk wawancara (interview), untuk mengamati langsung (observasi), dan teknik pengambilan sempel.

\section{HASIL DAN PEMBAHASAN \\ Analisia Permasalahan}

Dari hasil yang penulis lakukan maka penulis dapat menganalisis permasalahan yang ada pada PT.Inticakrawala Citra adalah dalam persediaan Barang pemilik mengalami kesulitan karena data persediaan barang hanya ditulis dibuku sehingga data tidak valid dan sering terjadi ketidaksamaan jumlah persediaan yang dicatat dengan jumlah yang ada.Serta dalam Penjualan terdapat Kelambatan dalam mencari data barang yang dibutuhkan.

\section{Alternatif penyelesaian masalah \\ Alternatif pemecahan masalah yang akan penulis lakukan untuk mempermudah proses kerja pada PT.Inticakrawala Citra adalah Merancang sistem aplikasi pengelolaan dan penjualan barang- barang GMS (General Marchandise) dengan sistem terkomputerisasi, sehinga setiap pemesanana, penerimaan, penjualan dan data laporan akan tersimpan ke dalam database.kemudian laporan yang di butuhkan akan ditampilkan secara otomatis tanpa harus mengunakan cara manual.}




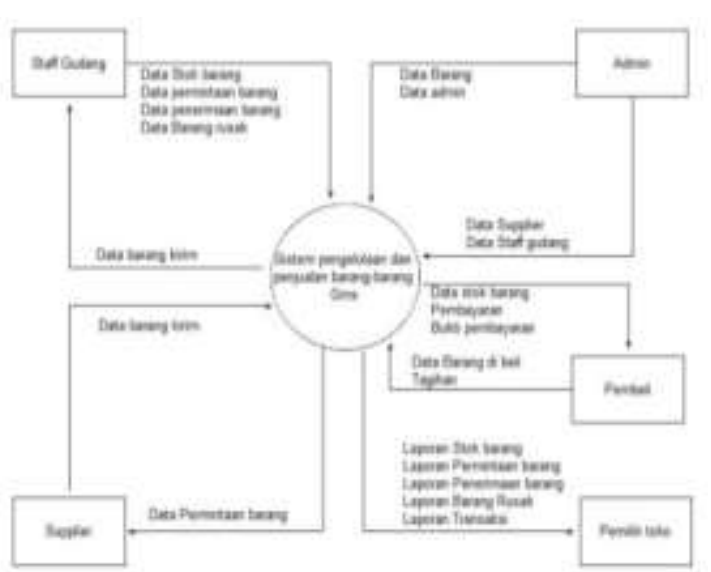

Gambar 1 .Diagram Konteks

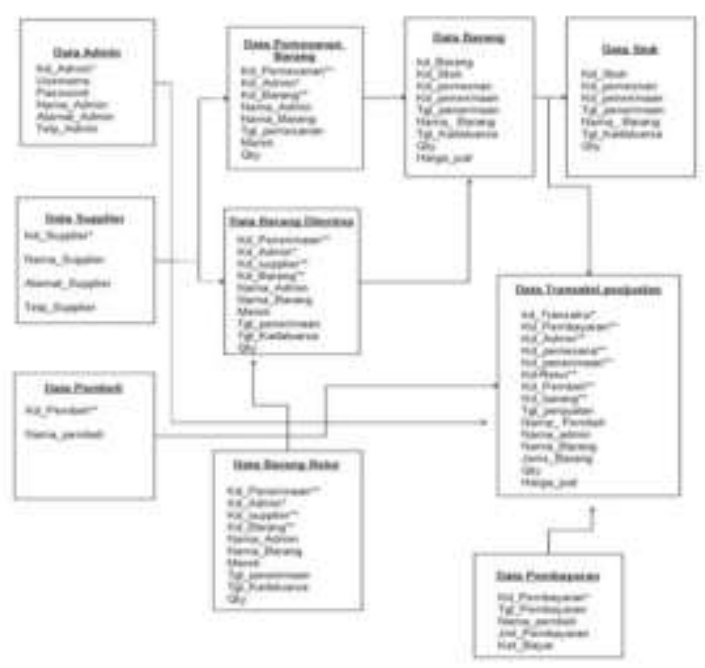

Gambar 2 .Diagram Konteks

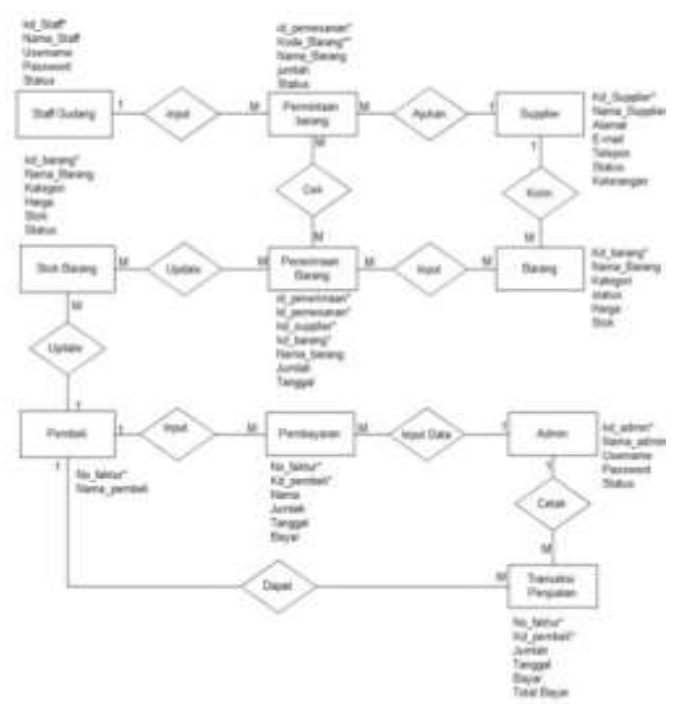

Gambar 3 . ERD (Entity Relationship Diagram)

Berikut adalah tampilan layar dan hasil pengujian pada software program yang telah di buat dengan bahasa pemrograman Java.

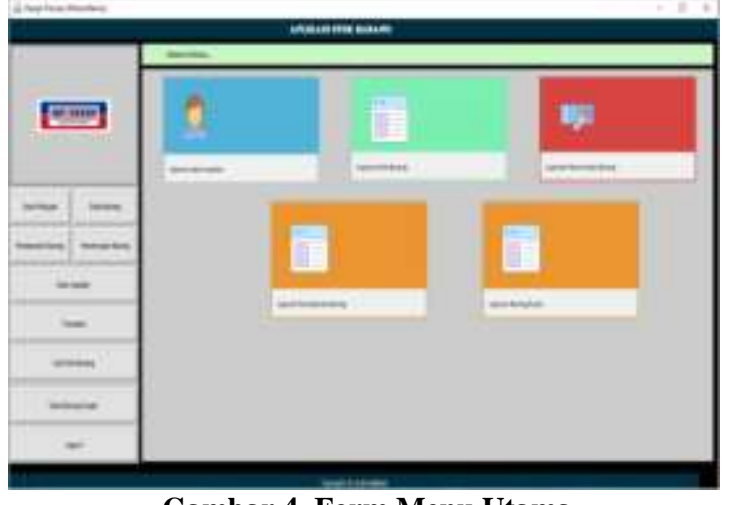

Gambar 4. Form Menu Utama

Tampilan menu utama ini terdapat beberapa icon menu yang akan menampilkan form-form transaksi diantaranya adalah data utama, master data, proses dan laporan.

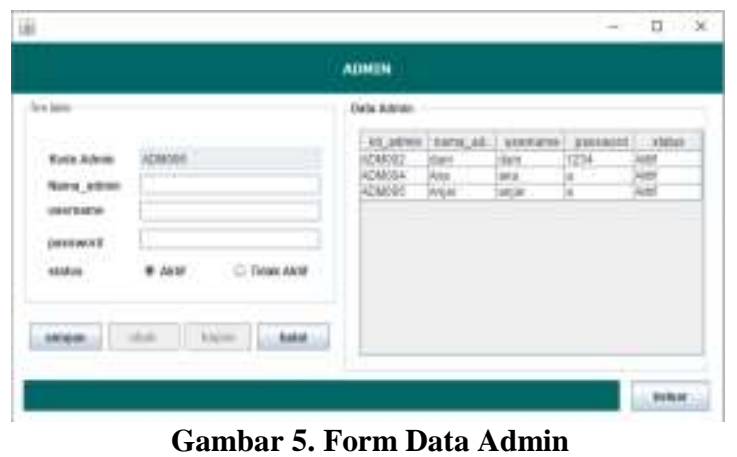

Tampilan form data admin ini, user dapat melakukan penambahan data admin dan staff gudang, mengubah, dan menghapus data admin. Masukkan id admin untuk melakukan pengecekan data-data yang sudah tersimpan. Lakukan pengisian apabila akan dilakukan penambahan data dan tekan tombol (simpan) untuk menyimpan data, untuk memperbarui data tombol (ubah), dan untuk menghapus data klik tombol (hapus). Pilih tombol (keluar) apabila ingin menutup form data petugas dan kembali ke tampilan menu utama.

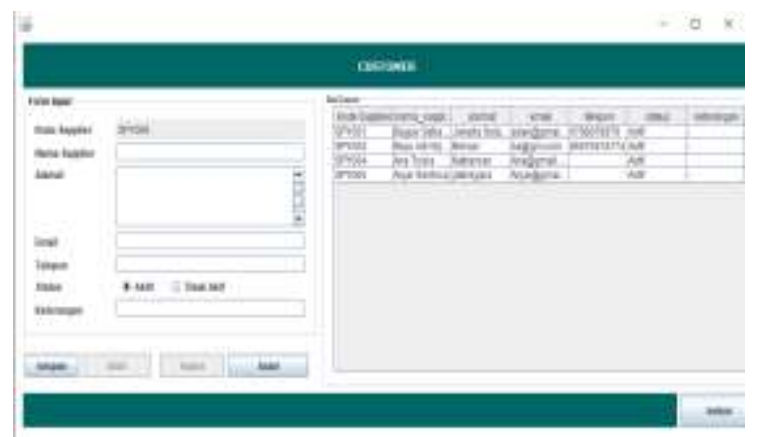

Gambar 6. Form Data Supplier

Tampilan form data supplier ini, user dapat melakukan penambahan data supplier, 
mengubah, dan menghapus data admin. Masukkan id petugas untuk melakukan pengecekan data-data yang sudah tersimpan. Lakukan pengisian apabila akan dilakukan penambahan data dan tekan tombol (simpan) untuk menyimpan data, untuk memperbarui data tombol (ubah), dan untuk menghapus data klik tombol (hapus). Pilih tombol (keluar) apabila ingin menutup form data petugas dan kembali ke tampilan menu utama.

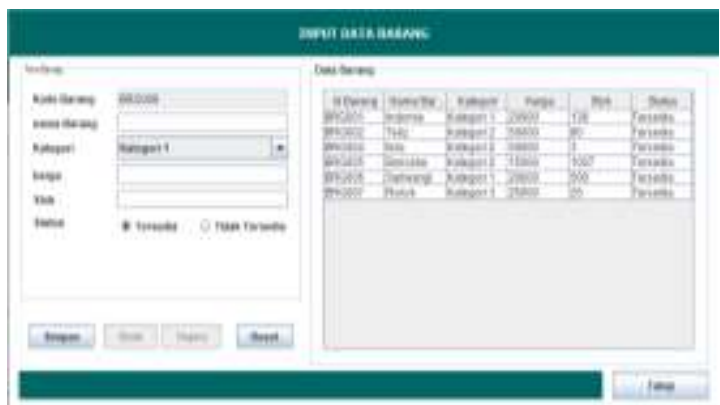

Gambar 7. Form Data Barang

Tampilan form data barang ini, user dapat melakukan penambahan data barang, mengubah, dan menghapus data admin. Masukkan kd barang untuk melakukan pengecekan data-data yang sudah tersimpan. Lakukan pengisian apabila akan dilakukan penambahan data dan tekan tombol (simpan) untuk menyimpan data, untuk memperbarui data tombol (ubah), dan untuk menghapus data klik tombol (hapus). Pilih tombol (keluar) apabila ingin menutup form data petugas dan kembali ke tampilan menu utama.

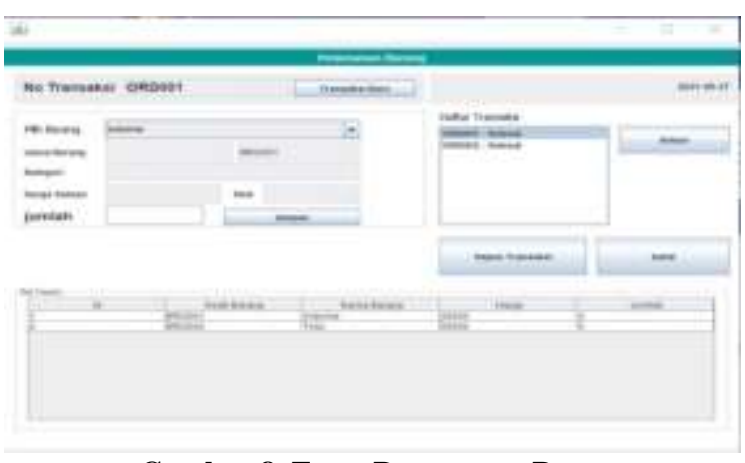

Gambar 8. Form Pemesanan Barang

Tampilan form data Pemesanan barang ini, user dapat melakukan penambahan data pemesanan barang, mengubah, dan menghapus data permintaan barang. Masukkan no transaksi untuk melakukan pengecekan data-data yang sudah tersimpan. Lakukan pengisian apabila akan dilakukan penambahan data dan tekan tombol (simpan) untuk menyimpan data, untuk memperbarui data tombol (ubah), dan untuk menghapus data klik tombol (hapus). Pilih tombol (keluar) apabila ingin menutup form data petugas dan kembali ke tampilan menu utama.

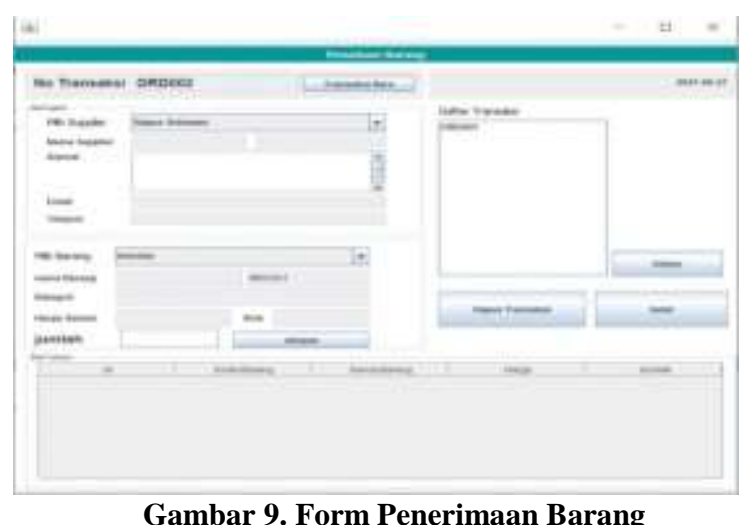

Tampilan form data penerimaan barang ini, user dapat melakukan penambahan data penerimaan barang, mengubah, dan menghapus data permintaan barang. Masukkan no transaksi untuk melakukan pengecekan data-data yang sudah tersimpan. Lakukan pengisian apabila akan dilakukan penambahan data dan tekan tombol (simpan) untuk menyimpan data, untuk memperbarui data tombol (ubah), dan untuk menghapus data klik tombol (hapus). Pilih tombol (keluar) apabila ingin menutup form data petugas dan kembali ke tampilan menu utama.

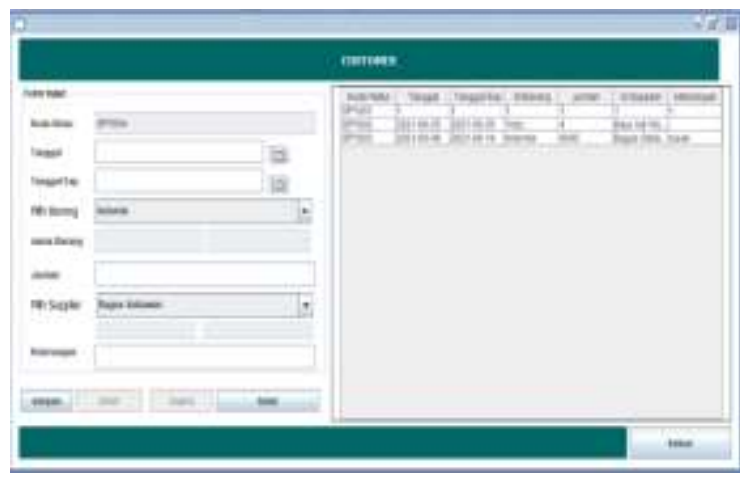

Gambar 10. Form Barang Rusak

Tampilan form data barang rusak dan kadaluarsa ini, user dapat melakukan penambahan data barang rusak dan kadaluarsa, mengubah, dan menghapus data barang rusak dan kadaluarsa. Masukkan kd retur untuk melakukan pengecekan data-data yang sudah tersimpan. Lakukan pengisian apabila akan dilakukan penambahan data dan tekan tombol (simpan) untuk menyimpan data, untuk memperbarui data tombol (ubah), dan untuk menghapus data klik tombol (hapus). Pilih tombol (keluar) apabila ingin menutup form 
data petugas dan kembali ke tampilan menu utama.

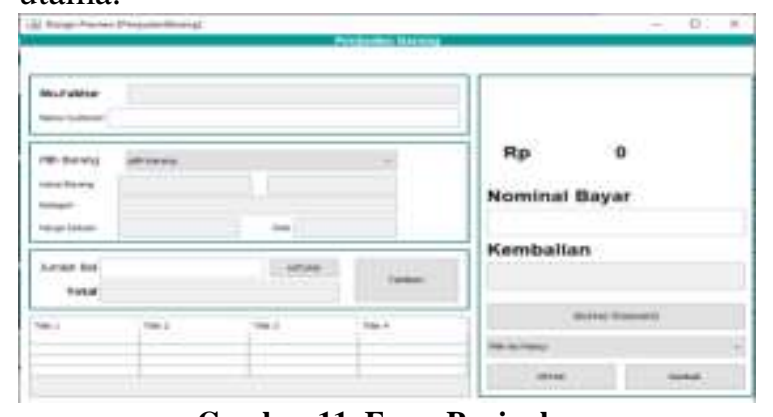

Gambar 11. Form Penjualan

Tampilan form data penjualan ini, user dapat melakukan penambahan data penjualan, mengubah, dan menghapus data penjualan. Masukkan no.faktur untuk melakukan pengecekan data-data yang sudah tersimpan. Lakukan pengisian apabila akan dilakukan penambahan data dan tekan tombol (simpan) untuk menyimpan data, untuk memperbarui data tombol (ubah), dan untuk menghapus data klik tombol (hapus). Pilih tombol (keluar) apabila ingin menutup form data petugas dan kembali ke tampilan menu utama.

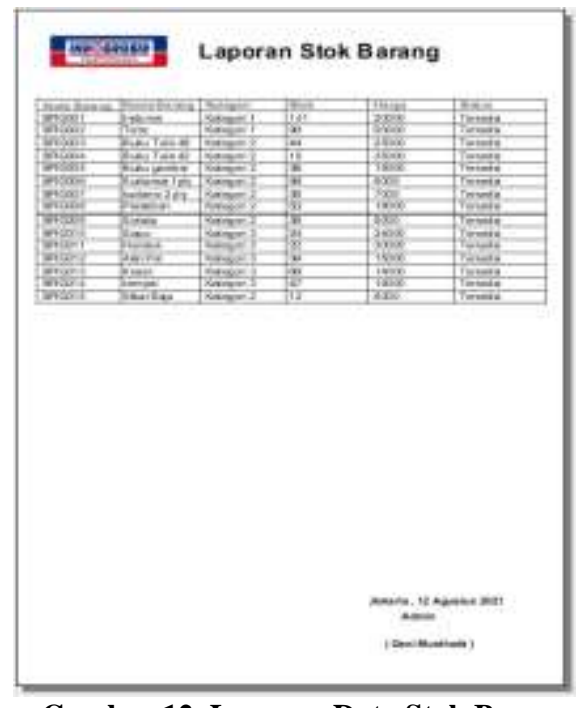

Gambar 12. Laporan Data Stok Barang

Layar di atas menampilkan tampilan form laporan data barang. Pada layar form laporan data Stok barang digunakan untuk mengecek stok barang terdiri Kode barang, Nama Barang, Kategori, Stok, Harga, Status

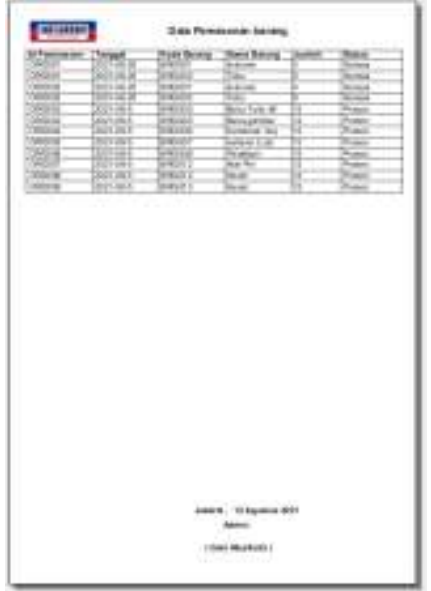

Gambar 12. Laporan Pemesanan Barang

Layar di atas menampilkan tampilan form laporan Pemesanan barang. Pada layar form pemesanan barang digunakan untuk mengecek laporan pemesanan barang terdiri id pemesanan , Tanggal, Kode barang, Nama barang, jumlah, Status.

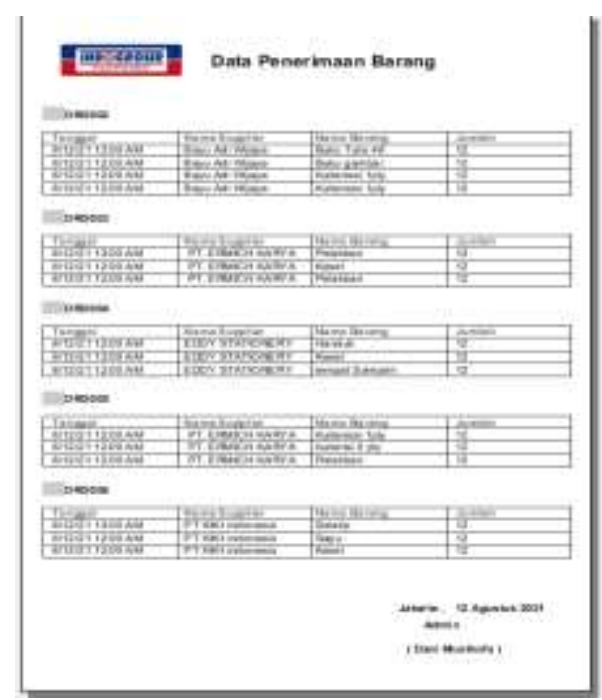

Gambar 12. Laporan penerimaan Barang

Layar di atas menampilkan tampilan form laporan penerimaa barang. Pada layar form penerimaan barang digunakan untuk mengecek laporan penerimaan barang terdiri kode pemesanan , Tanggal, nama supplier, Nama barang, jumlah. 


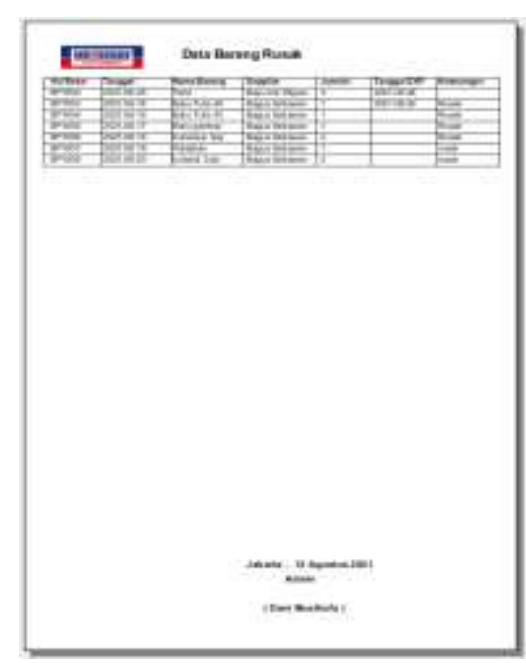

Gambar 13. Laporan Barang Rusak

Layar di atas menampilkan tampilan form laporan barang rusak. Pada layar form barang rusak digunakan untuk mengecek laporan barang rusak terdiri kode Retur ,

informasi Tanggal, Nama supplier, Nama barang, jumlah,Tanggal Exp, Keterangan.

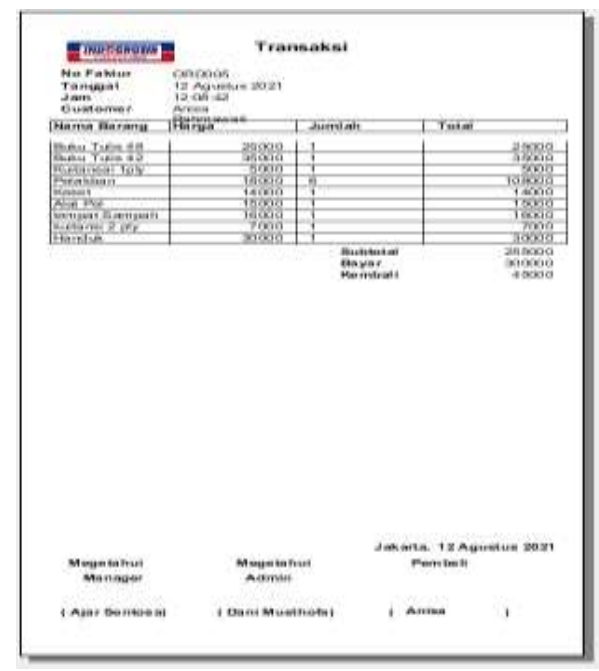

Gambar 14. Laporan Transaksi

Layar di atas menampilkan tampilan form laporan Transaksi. Pada Layar form laporan transaksi terdiri dari No faktur,Tanggal, jam, Nama customer, Nama Barang, Harga, Jumlah, Total, Sub total, Bayar, Kembali.

\section{SIMPULAN DAN SARAN}

Aplikasi Sistem pengelolaan dan penjualan barang barang GMS (General Marchandise) akan di perolah informasi yang efektif dan efisien yaitu dapat membantu dalam proses penyimpana data serta mempermudah dalam pembuatan laporan kepada pimpinan. Megetahui aplikasi sistem informasi pengelolaan dan penjualan barang GMS
(General Marchandise) yang sudah berjalan di PT INTICAKRAWALA CITRA sehinga dapat di ketahui permasalahan yang ada pada sistem informasi tersebut. Serta saran yang ingen penulis sampaikan adalah memperbaiki keamanan yang mana computer ini adalah alat yang sangat peka, maka keberadaannya harus dijaga dengan baik dan terawat dengan demikian resiko kehilangan dan kerusakan data akan semakin kecil tidak hanya itu guna mengatisipasi resiko kehilangan dan kerusakan data maka dilakukan backup data secara berkala .Serta perlu adanya pengawasan terhadap sestem yang di usulkan sehingan bila terdapat kelemahan dapat segera di perbaiki.

\section{DAFTAR PUSTAKA}

Eri mardiani, N. R. (2017). Membuat Aplikasi Penjualan Mengunakan Java Netbeans,Mysql,dan iReport. Jakarta: PT.Elex Media Komputindo.

Erwin. (2014). Perencangan Aplikasi Penjualan Barang Elektronik Di Toko Orlando Berbasis Java. Jakarta: Universitas Indraprasta PGRI.

Khasbi, I. N. (2016). sistem informasi peminjaman ruang dan barang di universitas muara kudus berbasis web mengunakan fitur sms notification. Retrieved from Jurnal Teknik Mesin, Elektro Dan Ilmu: https://doi.org/10.24176/simet.v7i2.76 2

Moekijat. (2011). Pengantar Sistem Informasi Manajemen. Bandung: CV. Remadja Karya.

Mulato. (2015). Perancangan Sistem Informasi Penjualan Mesin Hitung Uang Pada P.T. Segera Murni Mandiri. Jakarta: Universitas Indraprasta PGRI.

Nuariko, F. (2017). Rancang Aplikasi Sistem Pendukung Keputusan Pemilihan Karyawan Terbaik Menggunakan Metode Weighting Product. Jakarta: Universitas Indraprasta PGRI.

Sutabri, T. (2012). Analisis Sistem Informasi. Yogyakarta: Andi.

Sutanta, E. (2011). Basis Data Dalam Tinjauan Konseptual. Yogyakarta: Andi.

Sutarman. (2012). Pengantar Teknologi Informasi. Jakarta: Bumi Angkasa.

Tri Istikomah, W. P. (2013). Sistem Informasi Penjualan Roti Pada Home Industri Pitaloka Yogyakarta. 2. 
